\title{
Cenozoic tectonics and geodynamic evolution of the Tien Shan mountain belt as response to India-Eurasia convergence
}

\author{
Michael M Buslov†¥*, J ohan De Grave§ $₫$ and Elena A Bataleva\# \\ † United Institute of Geology, Geophysics \& Mineralogy, Siberian Branch-Russian Academy of Science, Novosibirsk, RUSSIA \\ $\ddagger$ Hokkaido University, Sapporo, JAPAN \\ \$ Department of Mineralogy \& Petrology, University of Gent, Gent, BELGIUM \\ $\checkmark$ Department of Geological \& Environmental Sciences, Stanford University, Stanford, USA \\ \# United Institute of High Temperatures RAS, Bishkek, KYRGYZSTAN
}

*To whom correspondence should be addressed.E-mail:misha@uiggm.nsc.ru

The present-day structure of the Tien Shan mountains consists out of roughly E-W trending, high mountain ranges (exceeding $7000 \mathrm{~m}$ ), alternating with (near) parallel sedimentary basins. The Tien Shan is situated in Central Asia at the boundary between the active orogenic structures of the northern Tarim plate and the stable Kazakhstan platform (Figure 1). The structural pattern of the Tien Shan indicates a complex Cenozoic deformational history with a current N-S shortening rate of $10-15 \mathrm{~mm} / \mathrm{yr}$ in the southern Tien Shan and 2-6 mm/yr in the northern Tien Shan. Moreover, shortening vectors from the northern and southern Tien Shan are oriented along different directions. These different shortening rates and orientations can be explained by the presence of the Precambrian Issyk-Kul microcontinent embedded in the northern Tien Shan region. The mosaic-block structure of the Tien Shan mountains is shaped by isometrically outlined Precambrian microcontinents (Tarim and Issyk-Kul) surrounded by Paleozoic island arcs and accretionary prisms that are dissected by Late Paleozoic-Early Mesozoic strike-slip faults. This complex structure of the Central Asian crust has a strong impact on the distribution of strain induced by the ongoing India-Eurasia convergence. In this study we investigate the relationships between the Cenozoic structure of the Tien Shan, reactivation of inherited faults, and interaction of rigid Precambrian microcontinents in the relatively mobile accretionary-collision belts (Buslov et al. 2003).

Northward propagation of the deformation front away from the Himalayan collision zone towards intracontinental Central Asia is suggested by systematic northward rejuvenation of mountain ranges and intramontane basins (Dobretsov et al. 1995). The model for this northward propagation may be described as follows: (1) India thrusting under Tibet, resulting in the uplift and rotation of the latter (35 to $20 \mathrm{Ma}$ ); (2) subsidence of the Tarim depression, Tarim under-thrusting the Tien Shan, rise of the southern Tien Shan (20 to $11 \mathrm{Ma}$ ); (3) reactivation of pre-existing structures around and within the Issyk-Kul microcontinent (10 to $3 \mathrm{Ma}$ ); (4) rise of the northern Tien Shan (peak at 3-2 Ma).

Apatite fission track thermochronology performed on crystalline basement rocks from the western and northern IssykKul basin showed that a first acceleration of rock uplift and denudation affected the northern Tien Shan starting between 20 and $10 \mathrm{Ma}$ ago, and a second acceleration occurred after 3 Ma ago. The latter is also expressed in the stratigraphy by a marked change in sedimentary environment in the Late Pliocene-Early Pleistocene, by thick sequences of coarse conglomerates, sedimentary gaps and tectonic unconformities. In the Paleogene, more than $3 \mathrm{~km}$ of lacustrine sediments were deposited in the subsiding basin. The onset of uplift of the southern Tien Shan started in the Neogene, when clastic and proluvial sediments, transported from the rising southern ranges were deposited in the basin. In this stage, the basin was much larger and more elongated than at present. It was probably controlled by ENE trending faults.

The thrusting of the Tarim plate under the southern Tien Shan results in the shortening of the upper crust at rates of $<10$ $15 \mathrm{~mm} / \mathrm{yr}$, whereas India moves northward at $50 \mathrm{~mm} / \mathrm{yr}$ (Abdrakhmatov et al. 2001). A part of the strain may have been accommodated within viscoelastic layers in the middle crust of the Tien Shan. Seismic and magneto-telluric studies show clear tectonic layering of the Tien Shan lithosphere, with several nearly horizontal viscoelastic layers. The lower layer is underthrust northward underneath the northern Tien Shan as indicated by seismic data (Figure 1b). Tectonic layering of the lithosphere beneath the southern Tien Shan is possibly related to the rotation and underplating of the Tarim plate and indentation of its basement into the middle crust of the southern Tien Shan. This caused high-rate slip and failure in the upper crust to depths of $20-30 \mathrm{~km}$ (Sabitova and Adamova 2001). Wave-guide lenses are found in the upper crust at a depth of $10-20 \mathrm{~km}$ north of the Pamir thrust sheets. Oblique wave-guide layers connect the horizontal layers. A clear change of the wave-guide is present along an EW profile at $42^{\circ} \mathrm{N}$ (profile II-II in Figure 1): its southern extremity is located $15 \mathrm{~km}$ shallower than the northern one. These thick wave-guides are absent beneath the Fergana depression and adjacent flats. Magneto-telluric studies in the Tien Shan (Rybin et al. 2001) also indicate the presence of the abovementioned layers and lenses with a high electric conductivity. Profile II-II shows the position of the low seismic wave area (seismic data) and high conductivity layers (magnetotelluric data). There is a good correlation between the results obtained by the different methods. A $15-25 \mathrm{~km}$ thick layer is located at a depth of $35-50 \mathrm{~km}$ to the north of $42^{\circ} \mathrm{N}$ and at a depth of 20-35 km to the south of $42^{\circ} \mathrm{N}$. Oblique wave-guides mark the southern border of the Issyk-Kul microcontinent (Buslov et al. 2003).

The upper crustal strain has been mainly controlled by the Issyk-Kul microcontinent. This lens-shaped microcontinent is surrounded by vast shear zones that have been involved in the tectonic activity during most of the Cenozoic. During the Quaternary the strain has propagated as far as the central part of the Issyk-Kul basin. Activity in the northern Tien Shan reached its peak in the Pliocene-Early Quaternary and resulted in the formation of the present-day topography and strong deformation of the Issyk-Kul basement and its Cenozoic cover. The strike of regional compression changed from NW-SE in the Late Miocene to N-S in the Pliocene-Early Quaternary. Both the southern and northern margins of the microcontinent were gradually deformed and uplifted, hence reducing the area of deposition in the basin. Due to thrusting of the northern and southern margins, the basin morphology at both the western 
and eastern end can be described as full-ramp structures. Underthrusting of Tarim along the southern Tien Shan resulted in segmentation of the southern margin of the Issyk-Kul microcontinent into several blocks separated by obliquethrusts and strike-slip faults. Strike-slip along the Chon-Kemin fault resulted in thrusting and reverse faulting along the northern margin of themicrocontinent. Themostimportantactivetectonic movements affecting the Issyk-Kul region today are sinistral strike-slip motions along the Chon-Kemin, Chon-Aksu, PredKungei, North Issyk-Kul and South Issyk-Kul faults. Strike-slip faulting probably was responsiblefor theformation of a pull-apart structure in the central part of the basin.

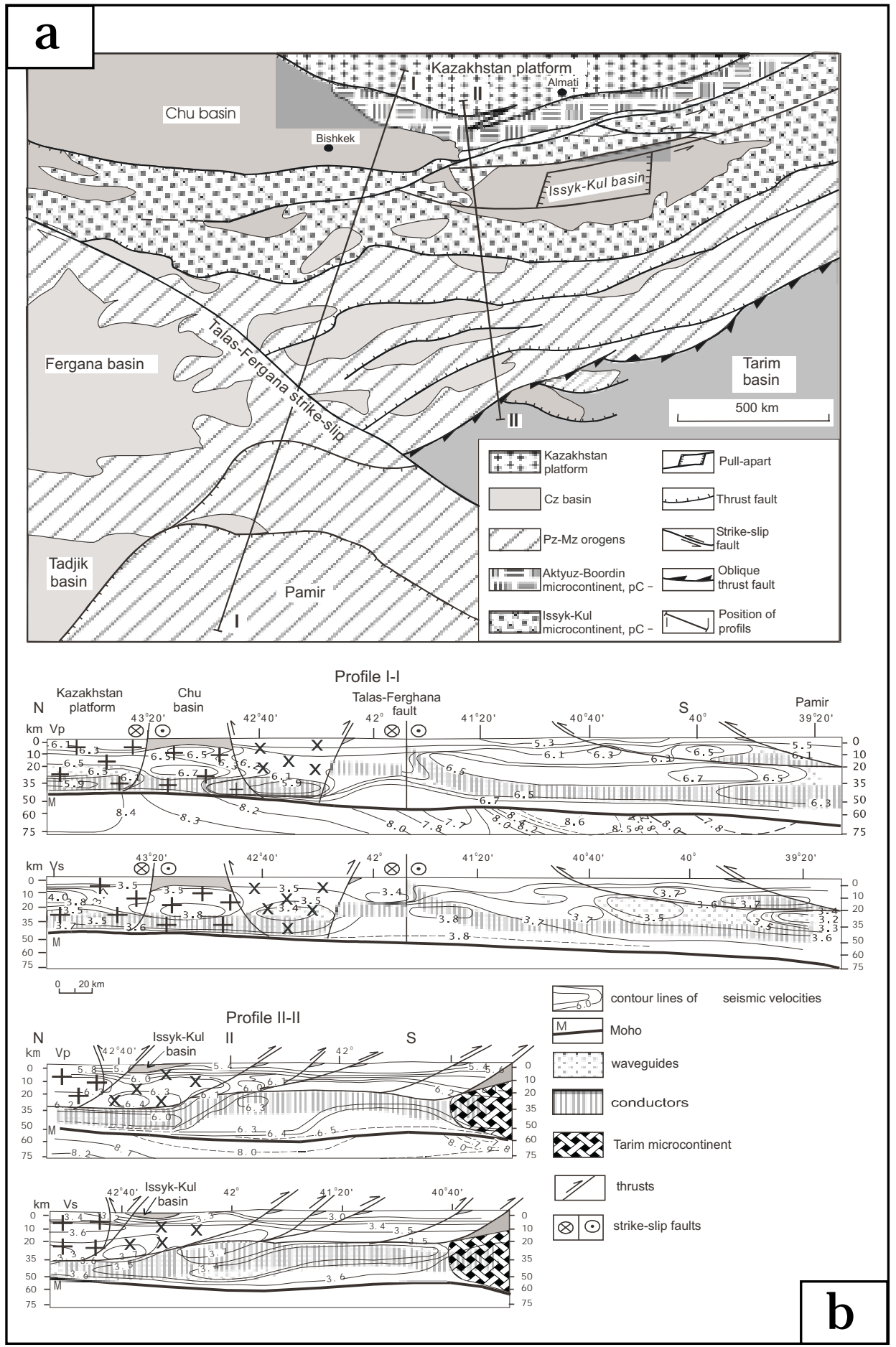

FIGURE 1. (a) Tectonic scheme of the Tien Shan Mountains. (b) Geophysical profiles within the study area (see a for location)

\section{References}

Abdrakhmatov KE, R Weldon, S Thompson, D Burbank, $\mathrm{CH}$ Rubin, M Miller and P Molnar. 2001. Origin, direction, and rate of modern compression of the central Tien Shan (Kyrgyzstan). Russian Geology and Geophysics 42(11-12): 1585-1609

Buslov MM, J Klerkx, K Abdarakhmatov, D Delvaux, VY Batalev, OA Kuchai, D Dehandschutter and A Muraliev. 2003. Recent strike-slip deformation of the northern TienShan. In: Stori F, RE Holdsworth and $\mathrm{F}$ Salvini (eds). Intraplate strike-slip deformation belts. Geological Society. London. Special Publication 210: 53-64

Dobretsov NL, MM Buslov, D Delvaux, NA Berzin and VD Ermikov. 1996. Meso- and Cenozoic tectonics of the Central Asian mountain belt: effects of lithospheric plate interaction and mantle plumes. International Geology Review 38 : 430-466

Sabitova TM and AA Adamova. 2001. Seismic tomography study of the Tien Shan crust: (results, problems, and prospects). Russian Geology and Geophysics 42(11-12): 1543-1553

Rybin AK, VY Batalev, PV II'ichev and GG Shchelochkov. 2001. Magnetotelluric and magnetovariational studies of the KyrgyzTien Shan. Russian Geology and Geophysics 42(11-12): 15661573 